\title{
Early Spanish Intruders in China: The 1579 Mission of Pedro de Alfaro, O.F.M., Reconsidered
}

\author{
Ubaldo Iaccarino \\ Research Institute for the Humanities and Social Sciences, National Taiwan \\ University, Taipei, Taiwan \\ ubaldoiaccarino@gmail.com
}

\begin{abstract}
In 1579, four years after the visit of the Augustinian missionaries Martín de Rada and Jerónimo Marín to Fujian, a new group of Spanish friars reached China from the Philippines. The mission of Pedro de Alfaro, O.F.M., has generally been dismissed as a useless attempt to break the spiritual monopoly of the Society of Jesus in East Asia, which was perceived as an attempt to put at risk the careful labor of the first generation of Jesuit "giants." However, as this study shows, the arrival of the Franciscans in Guangzhou cannot be simply regarded as a reckless behavior to "smuggle" the Gospel in China by means of some local Cantonese convert. Alfaro and his brethren pursued a specific goal, which was related to the recent achievements of Spanish diplomacy. Rather than Guangdong, they tried to reach the coast of Fujian (Chincheo), to carry on the mission of the Augustinians, who had visited Fuzhou in 1575. With the indirect support of some local encomenderos, the Franciscans intended to take advantage of the words of "friendship" expressed by Governor Liu Yaohui and other Mandarins to Rada and his fellows. Through a comparative analysis of European and Chinese coeval sources, notably some unpublished letters and reports, this article offers a reinterpretation of the aims and results of the Alfaro mission, shedding new light on a well-known but not yet fully explored page of the history of the early Christian presence in China.
\end{abstract}

\section{Keywords}

Franciscans - Pedro de Alfaro - Sino-Spanish trade - Sangley networks - trade diplomacy - Philippines 
The Spaniards settled in Cebu in 1565, when Miguel López de Legazpi (d.1572) reached the Visayas from Mexico. The Basque adelantado was joined by a group of Augustinian missionaries, notably the celebrated friars Andrés de Urdaneta (d.1568) and Martín de Rada (1533-78), who initiated the evangelization of the natives and laid the foundations of the Province of the Most Holy Name of Jesus of the Philippines (Santísimo Nombre de Jesús de Filipinas). ${ }^{1}$ Throughout the early years of Spanish conquest and settlement, they benefited from a virtual monopoly in spreading the Gospel among the "pagans" and the "infidels" of several regions, including Manila and the north-western coast of Luzon. It was not until 1578 that this monopoly came to an end with the arrival of the first Franciscans from Mexico. ${ }^{2}$

Pedro de Alfaro $\left(c .1525^{-80}\right)$ reached the Philippines at the beginning of July alongside a group of fourteen brethren who mostly came from Spain. The newcomers settled down in Manila and soon thereafter moved to the principal provinces of the archipelago to help the Augustinians in their task of evangelization. The Franciscans established themselves in Camarines, Panay, and Cebu, as well as in northern Luzon, where they took charge of the Augustinian missions in Ilocos and Pangasinan. ${ }^{3}$ At that time, the Philippines were still largely unexplored, especially the regions to the north of Manila, and it took the Spaniards more than ten years to assume control of the entire coastal region from Batangas to Aparri. By 1578, the conquistadores had settled in Ilocos (Bigan = Villa Fernandina) but they were still engaged in the pacification of Cagayan at the northern tip of Luzon.

Ships from China were regularly sailing to Manila and to several other ports of trade in the provinces of Pangasinan, Ilocos, Cagayan, Batangas, and the island of Mindoro. In the Philippines, the Chinese bought gold, cotton, forestry, and marine products, as well as American and Japanese silver, which reached Manila in the form of bullions and coins. On Alfaro's arrival from Mexico, there were already hundreds of Chinese living in the city and its surroundings. The Franciscans established contacts with some of them and had others converted to Christianity. ${ }^{4}$

1 It was officially erected in 1575 .

2 The Jesuits came in 1581, and the Dominicans only in 1587 . The latter took charge of the Chinese Christian community in Baybay and were assigned the evangelization of the province of Cagayan. The Jesuits mostly evangelized the south of the country (Visayas and Mindanao).

3 Marcelo de Ribadeneira, O.F.M., Historia de las islas del archipiélago filipino y reinos de la Gran China, Tartaria, Cochinchina, Malaca, Siam, Cambodge y Japón, ed. Juan Legísima, O.F.M. (Madrid: Editorial Católica, 1947), 40-41.

4 Ribadeneira, Historia, 74. 
It is important to point out that the majority of the "sangley" captain-merchants sailing to Luzon came from the ports of southern Fujian(Minnan 闽南). Some of them were linked to the most influential lineages of the region and were supported by the local gentry. ${ }^{5}$ After the lift of the ban on maritime activities ( haijin 海禁) of ${ }^{1567}$, trade between China and the Philippines mostly fell in the hands of a restricted number of Hokkien traders who quickly expanded their networks in and around Luzon. ${ }^{6}$ It is no coincidence that almost all the missions sent to China at the end of the sixteenth century relied on the mediation of some Fujianese merchants who traded in Manila and had established contacts with the Spanish missionaries.

Since no foreigner was permitted to enter China without a formal invitation from the mandarins, the trade channel of the sangleys became de facto the only viable route to take. ${ }^{7}$ This route, however, was a risky one. Not a few captain-merchants who sailed to the Philippines at the beginning of the $1570 \mathrm{O}$ were smugglers, and sometimes even former "pirates." ${ }^{8}$ Francisco "Zanco" and Lin Bixiu 林必秀 (“Sinsay"), for example, are two such men. The first had moved from Panay to Manila in 1569 along with the group of Miguel de Legazpi. He taught some rudiments of Chinese language to Martín de Rada, and in 1573 promised to bring two Augustinian friars to China on board his own

5 Chang Pin-tsun 張涁村, “Chinese Maritime Trade: The Case of Sixteenth-Century Fu-chien (Fukien)” (PhD diss., Princeton University, 1983), 217-34. The term sangley (生理, 商來, 常來) refers to the Chinese traders in the Philippines.

6 James Kong Chin, "Junk Trade, Business Networks and Sojourning Communities: Hokkien Merchants in Early Maritime Asia," Journal of Chinese Overseas 6, no. 2 (2010): 157-215; Roderich Ptak, "Ming Maritime Trade to Southeast Asia, 1368-1567: Visions of a System," in From the Mediterranean to the China Sea: Miscellaneous Notes, ed. Claude Guillot et al. (Wiesbaden: Harrassowitz, 1998), 157-92; Nakajima Gakushō 中島楽章, “Jūroku seiki matsu no Fukken, Firipin, Kyūshū bōeki”十六世紀末の福建・フィリピン・九州貿易, Shien 史淵 144 (2007): 55-92; Li Jinming 李金明, "Mingchao zhongye Zhangzhou Yuegang de xingqi yu Fujian de haiwai yimin” 明朝中葉漳州月港的興起與福建的海外移民, in Zhongguo haiyang fazhan shi lunwen ji中國海洋發展史論文集, ed. Tang Xiyong 湯熙勇, 10 vols. (Taipei: 中央研究院人文社會科學研究中心, 2008), 10:65-100; Chao Zhongchen 昆中辰, Mingdai haijin yu haiwai maoyi 明代海禁與海外貿易 (Beijing: Renmin chubanshe, 2005), 230-34.

7 "Ben sapevamo che vi era pena della vita l'andarvi senza 'l loro consenso." Giovan Battista Lucarelli, Viaggio dell'Indie [Biblioteca Apostolica Vaticana, Vat. lat. 5565], in Sinica franciscana, ed. Anastasius van den Wyngaert, O.F.M., 11 vols. (Firenze: Quaracchi, 1933), 2:12-92, here 49.

8 On the multilayered identity of early modern East Asian "pirates" (wokou/wakō 倭寇, haikou/kaikō 海完, kaizoku 海賊), see Robert Antony, ed., Elusive Pirates, Pervasive Smugglers: Violence and Clandestine Trade in the Greater China Seas (Hong Kong: Hong Kong University Press, 2010); Tonio Andrade et al., eds., Sea Rovers, Silver, and Samurai: Maritime East Asia in Global History, 1550-1700 (Honolulu: University of Hawai'i Press, 2019). 
ship. ${ }^{9}$ The second sailed to Fujian in 1575 acting as adviser for the Spanish delegation dispatched by Guido de Lavezaris (c.1512-c.1582), the second governor general of the Philippines (in office $1572-75) \cdot{ }^{10} \mathrm{He}$ translated into Chinese the letters of the governor to the emperor of China and to some local mandarins. Yet "Sinsay" was not a diplomat but rather a smuggler with a turbulent past. He was in fact an old acquaintance of Lin Feng (林鳳, “Limahón”), the Chinese pirate who attacked Manila at the end of November $1574 .{ }^{11}$

Notwithstanding, the Franciscans, much like the Augustinians before them, decided to trust the promises of some captain-merchants met in Manila and tried to enter China through their good offices. After a series of failed attempts, the occasion seemed to arise in the spring of 1579, when Pedro de Alfaro received the visit of a Daoist priest who was said to have come to Manila on purpose to study the Christian doctrine. The man was hosted by the Franciscans, and soon converted to Christianity. Thus, according to his great desire to see the friars in his country he promised to bring them to Haicheng on a Chinese junk, which was going to leave from a port in Mindoro. However, while they were almost ready to go, just like the Augustinians before them, the Franciscans came to know that the captain of the ship had suddenly changed his mind, and the plan had thus to be abandoned. Later, it came out that the true intention of the priest was to get rid of the friars in the sea after having taken money from them. ${ }^{12}$

9 Agustín de Albuquerque and Francisco de Ortega. See Henry W. Scott, Barangay: SixteenthCentury Philippine Culture and Society (Manila: Ateneo de Manila University, 1994), 74; Juan Gil, Los chinos en Manila: Siglos XVI y XVII (Lisboa: Centro Científico e Cultural de Macau, 2011), 25-26.

10 Tang Kaijian 湯開建, “Ming Longwan zhi ji Yuedong ju dao Lin Feng shiji xiang kao-yi Liu Yaohui 'Dufu shiyi' zhong Ling Feng shiliao wei zhongxin” 明隆萬之際粵東巨 盗林鳳事蹟詳考——以劉堯誨《督撫疏議》中林鳳史料為中心, Lishi yanjiu 歷史 研究 6 (2012): 43-65, here 56; Charles R. Boxer, ed., South China in the Sixteenth Century (Bangkok: Orchid Press, 2004), xliv; Ch'en Ching-ho, The Chinese Community in the SixteenthCentury Philippines (Tokyo: The Centre for East Asian Cultural Studies, 1968), 49-51.

11 On Lin Feng's attack to Manila, see Emma Blair and Alexander Robertson, eds., The Philippine Islands 1493-1803, 55 vols. (Cleveland, Ohio: The Arthur H. Clark Company, 1903-9), vol. 4; Juan González de Mendoza, O.S.A., Historia del Gran Reino de la China (Madrid: Miraguano/ Polifemo, 20o8), 163-76; Gaspar de San Agustín, O.S.A., Conquistas de las islas Filipinas, ed. Manuel Marino, O.S.A. (Madrid: CSIC, 1975), 404-36; Ch'en, Chinese Community, 37-48.

Agustín de Tordesillas, Relación del viaje que hezimos a la China, nuestro hermano Fr. Pedro de Alfaro con otros tres frailes de la Orden del seraphico padre S. Francisco de la provincia de $S$. Joseph en el año del Señor 1579 (Archivo General de Indias [hereafter AGI], Patronato 46, r. 11), in Sinica Franciscana, ed. Anastasius van den Wyngaert, O.F.M., 11 vols. (Florence: Quaracchi, 1933), 2:103-6o, here 111. 
It goes without saying how dangerous the Franciscan task was and how foolish could be the idea to rely on such Chinese captains and trust their promises. Once in Guangzhou, Alfaro would warn his confrère Juan de Ayora (d.1581) to never trust the sangleys, "because they all lie and cheat," he wrote, and he vividly recommended to baptize them only "in articulo mortis."13

\section{$2 \quad$ Reaching for the Moon}

In light of the difficulties encountered with the sangley captains, the Franciscans decided to change strategy. Hence, they found the help of an old Spanish official, Rodrigo de Frías Albórnoz (d.1580), who was one of the most influential men in Manila and a member of the cabildo (city council). Frías provided the friars with a ship (a small frigate), on which they sailed to China on June 14, 1579. Pedro de Alfaro was accompanied in his mission by three brethren-Agustín de Tordesillas (d.1629), Sebastián de Baeza, ${ }^{14}$ and Giambattista Lucarelli (1540-1604), ${ }^{15}$ three soldiers—Juan Díaz Pardo (d.1616), Francisco de Dueñas, and Pedro de Villaroel, a Chinese boy (muchacho chino) called Juanillo (or Juanito), who served as interpreter, and a crew of up to fourteen native sailors. ${ }^{16}$

The group intended to reach the province of Fujian, but principally because of contrary winds, their ship was pushed off the coast of Guangdong and ended up not far from the mouth of the Pearl River. They eventually continued to sail upriver until they reached the port of Guangzhou where they finally landed on June 21.

Once in Guangzhou, Alfaro and his confrères were received by the local authorities and brought in front of several magistrates. In August, they moved to Zhaoqing, the political center of the region, where they had a brief audience with the governor of the two Guang (Liang Guang zongdu 兩廣總督), Liu Yaohui 劉堯誨. ${ }^{17}$ According to Alfaro's account of the audience, the "viceroy" (visrey), as Liu was called by the Spaniards, made only three questions: namely, he asked who they were, why they had come to China, and what kind

\footnotetext{
13 AgI, Filipinas 79, n. 5; AG I, Filipinas 84, n. 14 (Alfaro to Ayora, October 13, 1579).

14 Sebastián de San Francisco (d.1579).

15 Giovan Battista da Pesaro.

16 AgI, Filipinas 79, n. 5; AG I, Filipinas 84, n. 14; Lucarelli, Viaggio, 48; Tordesillas, Relación, 113. Dolors Folch, "A trancas y barrancas: La expedición franciscana a China de 1579," in Viajeros en China y libros de viaje a Oriente, siglos XIV-XVII, ed. Rafael Beltrán (Valencia: Universitat de València, 2019), 203-26.

17 Liu Yaohui, a literati from the province of Huguang (Linwu county), held this office from 1579 to 1582. Boxer, South China, 329; Ch'en, Chinese Community, 50-51.
} 
of goods they were carrying. ${ }^{18}$ It is easy to recognize here the standard protocol for inspecting the credentials of a foreign trade mission. The friars answered that they were castellanos (Castilians) who had arrived from the Philippines to preach the gospel, and that they did not carry anything else except some books and paintings. ${ }^{19}$ However, it seems that the local interpreter-a former-Christian called Simão Rodrigues ("Simón") who had been working for the Portuguese in Macao - gave a false translation of most of their answers, saying that they had lost their way because of bad weather and were simply asking to return to their country. The Spaniards were not allowed to ask anything to the "viceroy," but only reply to his questions, because, in Alfaro's words, "one cannot speak or ask more than what he asks, but only answer."20

By the end of August, the Chinese authorities had decreed the expulsion of the foreigners from Guangzhou. Later on, Alfaro and Lucarelli moved to Macao, whereas the rest of the group came back to Manila via Fujian. ${ }^{21}$

The Spaniards stayed in Guangzhou from June 21 to November 10, 1579. While there, they received several letters from Macao. One came from the bishop, Melchior de Carneiro (1576-83), and others were sent by two secret supporters: the Macanese priest André Coutinho and an old Spanish man called Pedro Quintero, who had taken part to the expedition of Ruy López de Villalobos (1500-44) of $1543 \cdot{ }^{22}$ During a period of almost six months no contact occurred between the Franciscans and the Jesuits. Only at the beginning of November, a letter sent by Coutinho to Pedro de Alfaro finally announced the visit of the Jesuit Michele Ruggieri (1543-1607) to Guangzhou along with two Portuguese merchants. ${ }^{23}$ The Italian missionary was probably chosen to check the identity of the friars. According to Coutinho, Ruggieri himself had declared to be an old acquaintance of Giambattista Lucarelli, whom he had probably met in Napoli

18 "Y lo que se le habló fueron tres palabras solas" (AGI, Filipinas 79, n. 5).

19 According to Lucarelli, the interpreter told they were "Falanque yen" (Folangjiren 佛郎機人). Lucarelli, Viaggio, 56 .

20 "No ay de hablar ni preguntar más de lo que él pregunta, solamente responder" (AGI, Filipinas 79, n. 5).

21 Villaroel went with them dressed up like a Portuguese.

22 Francisco Colín, S.J, Labor evangélica, ministerios apostólicos de los obreros de la Compañía de Jesús, fundación y progressos de su provincia en las islas Filipinas, ed. Pablo Pastells, S.J., 3 vols. (Barcelona: Imprenta y Litografía de Henrich y Compañía, 190o-2), 1:287.

23 "El padre Michael Rrogeiro, italiano, que este año pasado vino de Portugal, que allá va con dos portugueses a ver si puede alcançar alguna cosa de esos mandadores como V. Ras querían y pretendían" [Father Michael Rrogeiro, Italian, who this past year came from Portugal, who is going there with two Portuguese to see if he can get anything from those Mandarins as Your Reverences wanted and intended] (AGI, Filipinas 79, n. 6., Coutinho to Alfaro, November 1, 1579). 
(Italy) at the beginning of the 1570 os $^{24}$ In the end, however, the idea to meet was abandoned, partly because the Franciscans had already received the order to leave Guangzhou for Macao, and partly because Ruggieri, who had just arrived from Goa, still had very little knowledge about China and its people. ${ }^{25}$

At any rate, what is relevant here is that during the summer of 1579 rumors on the friars being spies of the "Castilians" had quickly spread throughout the province. Most likely, the Portuguese had contributed to their circulation in Guangzhou, principally out of fear of the Spanish ambitions and Manila's military plans. "All the mistrust," Alfaro wrote from Macao, "was for believing that a big army of Castilians would come against them, and that we had come as spies, to treat them badly and ruin their trade." ${ }^{26}$ At the end of July, the captain-major (capitão mór) of Macao, Miguel da Gama, had sent a note to the Chinese officers in Guangzhou to warn them from these men, stressing that the Portuguese had nothing to do with the "Castilians," and even if they shared the same religion, they had two different kings and countries. As a matter of fact, the haidao 海盜, who was in charge of the military affairs of the coast and controlled the flux of maritime trade, had already decreed the expulsion of the Spaniards at the beginning of July. It was Governor Liu Yaohui who preferred to postpone this decision and asked to send the friars to Zhaoqing. More important still, according to Alfaro, Liu Yaohui did not put much attention to Gama's despatch and decided to meet the friars "because he had already seen the Augustinians."27 I will return on this later on.

24 "El dicho padre me paresçe que irá deste su viaje a ir a ver a Cantón y a Vuestras Reverencias, que él particularmente desea mucho, y consolarse mucho con el padre Baptista, que me paresçe son ambos napolitanos y se an de conocer, según el padre me tiene acá dicho" [The said father seems to me that he will go from this trip to see Canton and Your Reverences, which he particularly desires very much, and to console himself with Father Baptista, for I believe they are both Neapolitans and must know each other, as the father has told me here] (AGI, Filipinas 79, n. 6).

25 Ruggieri arrived in Macao in 1579. His first visit to Guangzhou was in April of the next year. On the role of Ruggieri in the early Spanish missions to China, see Ubaldo Iaccarino, "Mediating the Spanish Ambitions in China: Michele Ruggieri's Involvement in the Missions of Pedro de Alfaro O.F.M. and Alonso Sánchez S.I. (1579-1583)," in Michele Ruggieri: Portrait of a Jesuit Missionary at the Dawn of the Dialogue between China and Europe, ed. Davor Antonucci et al. (Beijing: China Social Science Press 中国社会科学出版社, 202O).

26 "Todo el reçelo hera por creer que venía alguna armada de castellanos sobre ellos, y que no veníamos sino con espías, a tractalles mal o quitalles su tracto" (AG I, Filipinas 79, n. 8 [Alfaro to Tordesillas, November 2, 1579]).

27 "Porque ya havía visto a los padres agustinos." Tordesillas, Relación, 128; Boxer, South China, 329 . 
According to a letter from the governor and captain-general of the Philippines, Don Francisco de Sande (in office $1575^{-80}$ ) to Philip II, written on May 30, 1580, the ship that carried the mission of Pedro de Alfaro to China had sailed from the port of Bigan (Ilocos) with the intention of reaching "the city of Chincheo" (Zhangzhou 漳州, Haicheng 海澄/Yuegang 月港), in the "province of Hoquian" (la cibdad de Chincheo, en la provincia de Hoquian). ${ }^{28}$ Alfaro confirmed the target of the voyage. On October 13, 1579, he wrote a letter to Philip II informing that the ship's bow was pointed to "Chincheo." 29

My argument is that Alfaro and his confrères tried to reach Zhangzhou to carry on the mission of the Augustinians. In other words, they wanted to follow the diplomatic path opened by Martín de Rada and Jerónimo Marín, who visited Fujian in 1575 as official envoys of the governor of the Philippines. On that ocasion, the Chinese provincial authorities had expressed the possibility for the Spaniards to establish a trading post near Zhangzhou, where the friars could have settled on a stable basis. Rada himself had asked Governor Liu to stay in Fujian to learn Chinese, and the latter, according to the missionary, had agreed with that. Next time the friars would come, he guaranteed, they would be permitted to stay. ${ }^{30}$

Therefore, although the permission to settle was not immediately granted, Liu Yaohui left the friars with a promise that Alfaro and his confrères probably expected and wished to see fulfilled. Writing to the provincial of the Augustinians in Mexico, in 1577, Martín de Rada expressed in words the plan that the Franciscans were to follow in 1579: "There is a good chance to go there

28 "Se embarcaron [...] para tierra firme de China, diziendo que con intención de ir a la ciudad de Chincheo, que es en la provincia de Fokien" [They embarked (...) for the mainland of China, saying that they intended to go to the city of Chincheo, which is in the province of Fokien] (AGI, Filipinas 6, r. 3, n. 40).

29 AgI, Filipinas 79, n. 5; Ag I, Filipinas 84, n. 14. Cf. Ag I, Filipinas 79, n. 3 (Juan Díaz Pardo and Francisco de Dueñas to the Governor of Macao): “dimos las velas con intençión de hir a Chincheo [...] porque allí an estado ya españoles y dos padres agustinos que ffue quando vinieron a pedir el socorro contra Limahón" [we set sail with the intention of going to Chincheo (...) because Spaniards and two Augustinian fathers had already been there when they came to ask for help against Limahón].

30 "Respondionos el Conmun [...] a nuestra quedada que él se holgava de ello, pero no quería que fuese por entonces [...] y que a la buelta si quisiessemos quedarnos quedaríamos" (Relaçion verdadera de las cosas del reyno de Taibin, Bibliothèque Nationale de France, esp. 325 , fol. 19). 
[Fujian], even on a Spanish ship, by saying that they are coming to know the answer of the king [i.e., the Chinese emperor] to the letters we have carried."31

It is a well-known fact that throughout the sixteenth century the utopian myth of Cathay had put great expectations upon the missionaries of the Seraphic order, nourishing a strong desire to enter China. ${ }^{32}$ As Sande cynically remarked in one letter to the king, the Franciscans were sent to Manila principally to help the Augustinians in the evangelization of the Philippines, but since the latter had occupied the best provinces of the country (an tomado lo mejor de la tierra), with so many novices, Alfaro and his men found that the islands were too small a place for thirteen or fourteen of them (a los franciscanos les a pareçido que es poca cossa yslas para treze o catorze q vinieron). ${ }^{33}$ Bishop Domingo de Salazar (1579-94), a Dominican, would subtly comment that, due to the Franciscan peregrinations to China, many native converts were left "without instruction]," that he considered "a great disadvantage." However, "knowing that God moves the hearts of men (a matter that we cannot understand)," he decided to turn a blind eye to it. ${ }^{34}$

In fact, although a royal decree issued by Philip II in 1577 kept silent about the evangelization outside the Philippines, the papal brief De salute gregis dominici indirectly authorized the Friars Minor to spread the Gospel in East Asia (Indies). ${ }^{35}$ Hence, as soon as they reached Manila, the missionaries put pressure on Governor Sande (in office $1576-80$ ), to let them move on to China in order to carry out their evangelical duty.

However, it must be noted that the Franciscans were not just trying to set sail without any specific plan. As mentioned above, they intended to reach "Chincheo," that is, not a port at random, neither Guangzhou nor Macao, but

$31 \quad$ "Ay grande ocasion para yr alla aun en navio proprio de Castilla con dezir que van alla a saber la respuesta del rey de las cartas que nosostros llevamos" (Bibliothèque Nationale de

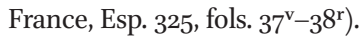
José Antonio Cervera Jiménez, "Los intentos de los franciscanos para establecerse en China, siglos XIII-XVII," Sémata 26 (2014): 425-46, here 430.

33 AGI, Filipinas 6, r. 3, n. 39.

34 Blair and Robertson, Philippine Islands, 5:250.

35 Ribadeneira, Historia, 37. The Franciscan Province of St. Gregory the Great was officially established in November 1586 with the bull Dum uberes. The brief De salute gregis dominici curae nostrae, which was issued in Rome on November 15, 1577, consecrated the missions of the Philippines and China to St. Gregory. Annales minorum seu Trium Ordinum a $S$. Francisco institutorum, 1575-1584, 21 vols. (Ancona: Ex typographia Josephi Aureli, 1844), 21:498 (no. XXXIII). "[...] quella bolla si favorevole, come si vede stampata per fondar detta Custodia di S. Gregorio nell'isole Filippine et nel regno di China” [that bull, so favorable, as we see printed to found the said Custody of St. Gregory in the Philippine Islands and in the kingdom of China] (Lucarelli, Viaggio, 32). 
Zhangzhou, in the province of Fujian. According to Tordesillas, the governor had "always tried to divert them from that intent, saying that it was too early, because there was very little friendship with the Chinese, and that the Augustinians had already tried to enter in that way, but they could not."36 These words seem to support the hypothesis that the Franciscans were proposing to Sande to resume the diplomatic talks with the Ming court.

The alacrity of the Friar Minors was probably caused by the recent plans of the Augustinians, who by the time in question were almost ready to send a new mission to China. ${ }^{37}$ Already in 1573 , in fact, the superior provincial of the order, Friar Diego de Herrera (1571-76), had been sent to Spain to find support to a project of embassy to Beijing on behalf of Philip II (r.1556-98), which was kept alive in the court by the Augustinian friar Juan González de Mendoza (15451618). Eventually, in August 1578, Jerónimo Marín presented himself in Madrid with the letters and reports of the embassy of $1575 .{ }^{38}$ By that time, Alfaro had just arrived in the Philippines.

Sande himself, in one letter to the king dated May 25, 1580, declared that he did not prevent the friars from sailing to China. On the contrary, it was he who suggested Alfaro to find a Chinese captain willing to carry them to Fujian. According to what the governor wrote, he would also pay the expenses of the trip. ${ }^{39}$ This fact corroborates the idea that the Franciscans were pushing for a resumption of the diplomatic talks initiated a few years before, in 1575, by the Augustinians.

Trade and Diplomacy

One of the principle aims of the mission of Martín de Rada and Jerónimo Marín was the acquisition of a trading post in China. The Spaniards carried letters and gifts for the local mandarins and had an interview with the "viceroy of Hogchiu," Liu Yaohui, which took place in Fuzhou 福州 (“Hogchiu”), the

36 "Él siempre procurava desviarlo de aquel proposito, diciendo que era muy temprano, porque havía muy poca amistad con los chinos, y que ya los padres agustinos havían intentado de ir de aquella manera, y no havían podido" (Tordesillas, Relación, 105). On the meaning of "friendship" (amistad), see António Vasconcelos de Saldanha, Iustum imperium: Dos tratados como fundamento do império dos portugueses no Oriente (Lisbon: Fundação Oriente, Instituto Português do Oriente, 1997), 353-83.

37 Ribadeneira, Historia, 37.

38 González de Mendoza, Historia, 152; Ollé, Empresa, 84-86.

39 "Que ellos negociasen con los mercaderes sangleyes que aquí bienen que los llevasen, que yo se lo pagaría" (AG I, Filipinas 6, r. 3, n. 39). 
capital city of Fujian..$^{40}$ At that time, Liu was holding the post of xunfu 巡撫, being responsible for the defense of the coasts. ${ }^{41}$ In addition to intelligence gathering and some Chinese printed books, Martín de Rada and his fellows came back to Manila with several letters, gifts, and most importantly with the promise of obtaining a trading post in Fujian. There, the Augustinians could have established a base for their missionary activities. ${ }^{42}$

The Chinese officials proposed the establishment of a tributary relationship on the same basis as the Ryukyus officialized with the sending of an embassy to Fujian "every three years" (de tres a tres años). ${ }^{43}$ According to this, a second Spanish embassy was expected to visit Zhangzhou in 1579, three years after the return of the Ming officer Wang Wanggao 王望高 (“Omoncon”) to China. The latter, in fact, sailed back to Manila in 1576 to carry on the negotiations between the former governor of the Philippines Guido de Lavezaris (in office 1572-76) and the Fujianese mandarins who acted on behalf of the Chinese emperor. ${ }^{44}$ However, a series of misunderstandings and disagreements with the Spaniards decreed the end of Wang's second visit to Manila and a sudden stop in the diplomatic talks. ${ }^{45}$ Governor Francisco de Sande, who later became a strong supporter of a military action against Ming China and even proposed a weary plan of conquest to the "prudent" King Philip, declared himself unwilling to accept the protocol of the Chinese tributary system and abandoned the idea of sending a new mission to "Chincheo." The above-mentioned tells us that, with all likelihood, the Franciscans were following in the Augustinians' footsteps, as they were trying to enter China, via Zhangzhou, through the official channels of trade and diplomacy.

According to a Chinese gazetteer of the early seventeenth century (Wanli Quanzhou fuzhi 萬曆泉州府志), the Spaniards applied for a tributary status like Siam (Xianluo 暹羅; Ayutthaya) and Cambodia (Zhenla 真臘). ${ }^{46}$ However,

40 Ch'en, Chinese community, 50-51; Ollé, Empresa, 60.

41 Tang Kaijian, "Ming Longwan," 44.

42 Ollé, Empresa, 6o. Bibliothèque Nationale de France, esp. 325.

43 "Carta del Inzanton de China de la provincia de Oquiam de la casa real," copied in Miguel de Loarca's account of his voyage to China (Real Academia de la Historia, Salazary Castro, ms. 9/1010, fols. $112^{\mathrm{r}}-15^{\mathrm{v}}$ ); San Agustín, Conquistas, 447-48 (Carta del Rey de Taybin, de la Provincia de Fokien, de la Casa Real); Blair and Roberson, Philippine Islands, vol. 23 (Letter from the Kingdom of Tangbin in the Province of Oc-kin, from the Royal House).

44 From the point of view of the Ming court, Lavezaris had asked the investiture of the Chinese emperor as the new “king” of Luzon (Lüsong wang 呂宋王).

45 Ollé, Empresa, $67-72$.

46 “上獻, 因請得入貢, 比於暹、臘諸國。”Yang Siqian 陽思謙et al., ed., Wanlichongxiu Quanzhou fuzhi 萬曆重修泉州府志 [1612] (Zhongguo shixue congshu 中國史學叢書, sanbian 三編, disiji 第四輯, 38), ed. Liu Zhaoyou 劉兆祐, 4 vols. (Taipei: Taiwan xuesheng shuju 臺灣學生書局, 1987), 3:268. 
it seems that the Fujianese mandarins had chosen a different status for them, matching the rank of the Philippines (Lüsong 呂宋) in the hierarchy of the tributary system to that of the Ryukyus (Liuqiu 琉球; “Lequios"). There is insufficient space here to explore the details surrounding the incongruity of the sources. Suffice it to say that upon arriving in Guangdong, the "Castilians" (Ganxilaren 干係臘人) were basically funneled into the Guangzhou trade system, which welcomed private missions from Southeast Asia, including Siam and Malacca. ${ }^{47}$ Interestingly, in Manila, not much was known about the Ryukyus. The Boxer Codex, for example, compiled at the beginning of the 159os, enlists the principal tributary countries of China but forgets to mention Okinawa and the other islands to the north of the Philippines. ${ }^{48}$ The fact is that, in the 1570s, the Spaniards had still very little knowledge about East Asia, and could hardly imagine the differences in status between Siam, Champa, Vietnam, and the Ryukyus. What is certain, however, is that they intended to gain a trading post in China no matter if in Fujian or in Guangdong.

A passage of a letter written in Manila by the above-mentioned Juan de Ayora in 1580 gives us some clue on the plans of the friars related to trade and diplomacy. While reminding Alfaro and his brethren to keep him informed about the developments of their presence in China, Ayora also asked them to discuss with the local mandarins the possibility "to go there to trade like those [merchants] from Siam." 49 The letter was written after the return to Manila, via Fujian, of Agustín de Tordesillas, Díaz Pardo, Dueñas, Juanillo, and the other members of the mission. Ayora's words seem to confirm our theory about the real intentions of the friars, who tried to enter China by means of the diplomatic channels of the sangley traders right from the start. In the eyes of the Spanish missionaries, it did not really matter if the port of entry was Zhangzhou or Guangzhou, since they did not know anything about the maritime trade regulations of the Mings and had no idea of the existence of the superintendencies for maritime trade (shibosi 市舶司). Alfaro and his men were just trying to take advantage of the promises made by the Fujianese mandarins and the sangley captain-merchants to the Augustinians in 1575 .

The entrance of the Catholic missionaries in China would have helped to stabilize the relationship with the overseas Chinese residing in the Philippines

47 Li Qingxin 李庆新, Mingdai haiwai maoyi zhidu 明代海外贸易制度 (Beijing: Shehui kexue wenxian chubanshe 社会科学文献出版社, 2007), 249-77.

48 George Bryan Souza and Jeffrey S. Turley, eds., The Boxer Codex: Transcription and Translation of an Illustrated Late Sixteenth-Century Spanish Manuscript Concerning the Geography, History and Ethnography of the Pacific, South-East Asia and East Asia (Leiden: Brill, 2015).

49 "Si oviere plática con los governadores de China será açertado saber si holgaran vamos allá a contractar como los de Siam" (AGI, Filipinas 79, n. 9). 
and stimulate the growth of Sino-Spanish trade. In Manila, many saw it as a concrete possibility to support and finance. After 1575, the establishment of a trading post in Fujian became an important goal that could be easily achieved through the channels of trade diplomacy. The Spaniards were aware of the possibility to enter China with the help of the mandarins, much like the Portuguese, who had obtained the permit to reside in Macao despite the failure in sending an embassy to Beijing. They knew that the Portuguese had settled there without an explicit permission of the Chinese emperor, and that their presence in China was guaranteed only by the good will (or better to say the interests) of some local officials, who received from them, in Sande's own words, "great briberies" (grandes cohechos) of silver and gold. ${ }^{50}$ So, far from being abandoned, the plan to enter China through diplomatic channels was still an on-going process that could be fulfilled by the friars. I will return on this issue in the last section of this article.

Benefits, of course, could arise from both sides. As far as Chinese interests are concerned, it is no coincidence that Governor Liu Yaohui asked to meet the friars in Zhaoqing. As mentioned previously, according to Tordesillas, the "viceroy" expressed the desire to see Alfaro and his brethren because he had already met the Augustinians in Fuzhou: "el visrey [...] dixo que nos quería ver, porque ya havía visto a los padres agustinos quando fueron a Chincheo, donde él entonces era visrey" ${ }^{\prime 51}$ Given that the verdict of expulsion of the friars had already been issued by the haidao at the beginning of July, when rumors about their being spies of the "Castilians" had probably reached Zhaoqing, and the Portuguese had sent their notes warning the local officials against the Spanish "ambitions," one may ask why did Liu want to meet the Franciscans. What reasons were behind his choice? Did the "viceroy" consider the Alfaro mission as a new diplomatic embassy from Lüsong?

In my opinion, there is no reason to exclude this possibility. Even though there is no way to ascertain the true intentions of the mandarins, still some considerations can be made. First, one should notice that Alfaro and his men were not put under arrest, as would happen later to Jerónimo de Burgos, Alonso Sánchez, and all the other Spaniards who came to China at the beginning of the 158 os. Alfaro and his brethren in fact were kindly hosted by the local officials and treated with all regards. More important still, the cost of their stay in Guangzhou was partially covered by the crown's treasury and their practices were entrusted to the bingbeidao 兵備道 (tinpintao), a military intendant

50 AGI, Filipinas 6, r. 3, n. 40.

$51 \quad$ "The viceroy [...] said that he wanted to see us, because he had already met the Augustinian fathers when they went to Chincheo, where he was then viceroy" (Tordesillas, Relación, 128). 
who was described by the friars as the "lieutenant" (teniente) of the "viceroy."52 According to Tordesillas, the Portuguese were greatly impressed by that, since after thirty years of presence in China they had never achieved such a goal. ${ }^{53}$

It should be noted that it was a common practice among the countries of East Asia to entrust some outstanding Buddhist monks with the credentials of diplomatic missions and tributary embassies. The monks could also act as commercial agents and intermediaries. ${ }^{54}$ During the early years of their presence in Asia, the friars were often associated with the Buddhists, much like the Jesuits before them.

The meeting between Pedro de Alfaro and Governor Liu took place in Zhaoqing at the end of August 1579. All the details of the audience are given by Tordesillas in his report. According to the Spanish friar, the "viceroy" inquired the missionaries about the purpose of their voyage and asked why they had sailed to Guangzhou without a license. Liu Yaohui probably had a different expectation about the reasons of their visit. In any event, he quickly found out that the "Castilians" had come to China without any official letter, with no presents, and not even with a clear purpose. After inspecting the ship and checking the few things that the friars were carrying with them from Manila (nothing of value except from a cup of silver), he probably got the picture. Accordingly, he confirmed the expulsion of the Spaniards from Guangzhou and put all matters concerning their repatriation in the hands of the haidao.

The reason for this is given by Tordesillas, who wrote that the Chinese would never accept any foreigner to live in China, "and especially the Castilians and Portuguese, because they have a prophecy," the friar explains, "telling that they will be subdued by a nation [whose people have] long beards, big noses, and cat's eyes." ${ }^{55}$ This is more or less what the Portuguese historian Diogo de Couto (c.1542-1616) had written a few years before, stating that as late as 1542 an imperial edict was posted up on the gates of Guangzhou forbidding the "men

52 Tordesillas, Relación, 140. "Nos dieron limosna muchas veces de la caxa del Rey." [We were given alms many times from the king's treasury] (AGI, Filipinas 79, n. 5). "Da parte del nostro Re gli darete pietanza per loro vivere, facendo inventario di quello che portano. Et il tutto sia ben custodito et sigillato col nostro sigillo" [On behalf of our king you will give them food for their living, making an inventory of what they bring. And the whole be well guarded and sealed with our seal] (Lucarelli, Viaggio, 57).

53 Tordesillas, Relación, 134.

54 A few years later, the Franciscans were sent to Kyoto as ambassadors of the king of Spain to Japan. Much the same happened in 1590 with the embassy of Alessandro Valignano (1539-16o6).

55 "En especial castellanos ni portugueses; porque tienen por prophecia que han de ser subjectados de una nación que tiene grandes barvas y largas narices y ojos de gato" (Tordesillas, Relación, 131-32). 
with the beards and large eyes" (os homens das barbas e olhos grandes) to enter the realm..$^{56}$ Far from being a fantasy of the friars' fervor or a suggestion of the myth of Cathay, these words are confirmed by the official correspondence of the mandarins. Two years later, in 1582, the governor of Guangzhou used the same expression when referring to another group of Castilian friars and soldiers who came along with the mission of the Jesuit Alonso Sánchez (1545-93). This letter partly explains the decisions of the mandarins also with regard to the Alfaro mission of 1579:

This frigate came from that island of Luzon to bring letter and presents. [However], on checking our laws, we found that it was not possible to receive the mission nor make friendship with these men because they are those that our laws say have cat's eyes, from whom we have to beware. ${ }^{57}$

One last aspect to consider is related to the level of autonomy in the decisions of the friars, and how they probably had been "pushed" to China. According to Alfaro and Tordesillas, the ship on which they sailed to Bigan was provided by Rodrigo de Frías Albórnoz to let them reach the province of Cagayan, where they should have given a contribution to the mission of "pacification" launched by Captain Juan Pablo de Carrión in the previous year. ${ }^{58}$ However, several points seem to refute the official version provided by the missionaries.

A passage of one of Alfaro's letters written in Guangzhou has it that Rodrigo de Frías had put at disposal not only the ship, but also one criado (a retainer, or servant) of his, whose identity remains unclear. Among the three soldiers sent along with the friars there was in fact no such kind of figure. ${ }^{59}$ Juan Díaz Pardo was, much like Frías himself, an old encomendero (he had been assigned an encomienda in Otón), whereas Francisco de Dueñas held the post of alcalde

56 Diogo do Couto, Décadas da Asia..., Década 5, lib. 8, cap. 12, 262-63. Cf. Chang T'ien-Tsê 張天澤, Sino-Portuguese Trade from 1514 to 1644: A Synthesis of Portuguese and Chinese Sources (Leiden: Brill, 1933), 71.

57 "Esta fregata benía de aquella ysla de Luzon a traer carta y presentes, y mirando a nuestras leyes hallamos que no se podía por ellas recivir esto ni hacer amistad con estos hombres porque son los que dizen nuestras leyes que tienen ojo de gato, de los quales nos debemos guardar" (Colín, Labor evangélica, 1:285-86).

58 Tordesillas, Relación, 108-9. AG I, Filipinas 79, n. 4 (Alfaro to Sande, October 12, 1579).

59 AGI, Filipinas 79, n. 4. 
mayor in the province of Bulacan. ${ }^{60}$ As for Pedro de Villaroel, he was residing in Bigan far away from Manila, and decided to follow the friars in their venture by his own choice. According to this, putting aside the Filipino sailors who run the ship, we have reasons to believe that this anonymous criado must have been the Chinese interpreter Juanillo.

Although there is no document attesting the presence of Juanillo aboard the ship, we have reasons to assume that the boy sailed to Bigan from Manila along with the Franciscan missionaries. This is not a secondary aspect since it would mean that from the beginning a plan had been carried out in the Philippines, at a local level, to help the friars entering China. One may ask in fact what was the use of carrying a Chinese boy to Cagayan. Unfortunately, Spanish sources remain silent on this point.

My argument is that Juanillo would have possibly served as a "connection" with the Hokkien traders in "Chincheo." The boy had been rescued from the gang of the pirate Lin Feng in 1574, and was probably a native of that region. ${ }^{61}$ That is proved by the fact that after reaching Guangzhou, Juanillo "stayed mute" (se hizo como mudo) the whole time, mostly because he had problems in understanding the local vernacular (Cantonese), as well as the Mandarin language (guanhua 官話). ${ }^{62}$ This is clearly stated by Governor Francisco de Sande, who wrote to the king that the boy "did not know well the language" (no sabía bien la lengua). ${ }^{63}$ With all probability, he only spoke Minnanhua or some Hokkien dialect. Writing to Juan de Ayora in October 1579, Alfaro warned his confrères that the language they were learning from the sangleys in Manila was quite different from the one spoken in Guangzhou. ${ }^{64}$

For all the above, we can thus assume, but only speculating, that the friars had found some local supporter in Manila apart from the afore-mentioned three soldiers, and that the spectrum of interests linked to the Alfaro's mission must have been wider. Rodrigo de Frías, for example, had one of his own encomiendas in Baratao, in the lands evangelized by Friars Giambattista Lucarelli and Sebastián de Baeza during their one-year stay in the region. ${ }^{65}$ The two missionaries started their work in Bantay, near Bigan (Ilocos), and then

6o He was at the time thirty-seven years old, and had been living in the Philippines since 1571, serving the crown as sergeant, alferez, and captain. Colín, Labor evangélica, 1:309.

61 González de Mendoza, Historia, 255.

62 AGI, Filipinas 79, n. 5; AGI, Filipinas 84, n. 14 (Alfaro to Ayora, October 13, 1579).

63 AGI, Filipinas 6, r. 3, n. 40 (Sande to Philip II, May 30, 1580).

64 "La lengua [...] no es la que Vuestra Caridad aprende, mas otra bien diferente." AG I, Filipinas 79, n. 5; AGI, Filipinas 84, n. 14 (Alfaro to Ayora, October 13, 1579).

65 Lucarelli, Viaggio, 42; Juan Francisco de San Antonio, O.F.M., Chrónicas de la Apostólica Provincia de S. Gregorio de religiosos descalzos de N.S.P. S. Francisco en las islas Philipinas, 
extended their activities to several other places, especially in the area of Agoo, in the province of Pangasinan (today's La Union), which included the territories of Baratao. This region had a long tradition of trade with China, Japan, and the Ryukyus.

Hence, one may argue that when Agustín de Tordesillas declared that their trip to China was supported not only by the pope but also by Philip II: "la intención de Su Magestad era que passassemos adelante" (His Majesty's intention was that we should go ahead) he may have referred not to the king himself nor to his court in Madrid, but to the "local" backing of the cabildo and some influential Spanish official. ${ }^{66} \mathrm{~A}$ decisive role must have been played by the encomenderos, who, as in the case of Rodrigo the Frías, represented the legal authority of the Spanish crown in the Philippines while pursuing at the same time their own private interests, due to their rights of independence. ${ }^{67}$ In support of this argument, it is worth noting that in the summer of 1580 , Juanillo was entrusted by Ayora to sail back to China with an important letter addressed to Pedro de Alfaro (who was still in Macao) to inform him about the sudden death of Rodrigo de Frías. ${ }^{68}$

\section{6}

\section{Concluding Remarks}

The mission of Alfaro has been generally presented as the first Spanish attempt to enter China through the port of Guangzhou. However, rather than the province of Guangdong, which was reached accidently, the principal target of the missionaries was "Chincheo," namely, the province of Fujian and more specifically the area of Zhangzhou. Far from being the only result of the spiritual fervor of the friars, who were moved by a strong desire to spread the Gospel among the Chinese, the Alfaro mission stemmed from the effects of the

China, Japón \&c., Parte Primera (Sampaloc, 1738), 519-20; Eusebio Gómez Platero, O.F.M., Catálogo biográfico de los Religiosos Franciscanos de la Provincia de San Gregorio Magno de Filipinas (Manila: Imprenta del Real Colegio de Santo Tomas, 188o), 19, 24-25. Two other missionaries, Pablo de Jesús and Alonso de Jesús Medina, had started the conversion of the natives in Pangasinan, probably in the area of Baratao. See AGI, Filipinas 79, n. 5; AGI, Filipinas 84, n. 14 (Alfaro to Ayora, October 13, 1579).

66 Tordesillas, Relación, 108. In a letter written to Philip II from Mexico in 1577 (AGI, México 283), Alfaro states that he had left Spain by order of the king "to journey to the Philippines and the kingdom of China" [por mandado de V.M. para hazer esta jornada a las Philippinas y reyno de la China], and speaks about missionaries going to China from Spain. However, whether the king was favorable or not is hard to ascertain.

67 I am grateful to the anonymous reviewers for their comments and suggestions on this point.

68 AGI, Filipinas 79, n. 9. 
embassy of Martín de Rada and was related to the early Spanish plans to enter China through the channels of trade and diplomacy. Following in the footsteps of their Augustinian brethren, the Franciscans sailed to China with a specific plan of resuming the diplomatic talks initiated in 1575 and settling in Fujian on a permanent basis.

The interests related to the Sino-Spanish trade in Manila played a decisive role. Alfaro found support at a local level from some Spanish officials lured by the benefits of Chinese trade but had to face the opposition of the governor of the Philippines, Francisco de Sande, who was unwilling to follow any diplomatic path. On the contrary, he strongly supported the idea of a military action against China. For their part, the Chinese officials saw the arrival of Alfaro and the other "Castilians" in Guangdong as a tentative to resume the diplomatic talks initiated in 1575 , and evaluated the possibility of allowing the Spaniards to trade in Guangzhou.

Given its aims and objectives, the Alfaro mission was far from being successful, and one can say that it ended up in a quite predictable failure. It inevitably affected the diplomatic intercourse between Manila and Fuzhou, and eventually took a toll on the early Spanish plans of obtaining a trading post on the coast of Fujian by triggering a massive and uncontrolled wave of missionary attempts to enter China, via Guangzhou, throughout the $158 \mathrm{os}$. Moreover, it marked a radical departure from the overall strategy of evangelization that prevailed among the Spanish missionaries in the early years of their presence in the Philippines.

In the light of the above, it is clear how the visit of the Franciscans to China was central to the developments of the Sino-Spanish diplomatic relations and to the future plans of evangelization of the mendicant orders outside the Philippines. Seen from this new perspective, the mission of Alfaro appears fundamental not only to a correct understanding of China's process of dealing with the Iberian powers, but also with the Catholic missionaries, from Manila as well as from Macao (Ruggieri first visited Guangzhou in 1580), in relation to their role as diplomats and trade mediators. 